\title{
Pengaruh Struktur Modal, Likuiditas, Tingkat Pertumbuhan, dan Efisiensi terhadap Profitabilitas
}

\author{
Desi Agustina dan Indra Widjaja \\ Program Studi Manajemen Fakultas Ekonomi \& Bisnis \\ Universitas Tarumanagara \\ Email: desi.agustina5435@gmail.com
}

\begin{abstract}
This study aims to examine the effect of capital structure, liquidity, growth rates, and efficiency on profitability. This study uses a non-experimental quantitative research design and a causal comparison method (Ex-post facto)with secondary data (data taken from the company's financial statements) from 41 companies in the Property, Real Estate, and Building Construction companies on the Indonesia Stock Exchange in the 2014-2017 period. The sample is determined by judgmental sampling technique. Hypothesis testing through multiple linear regression test. The results found that empirically capital structure has a positive and significant effect on profitability. Liquidity has a negative and not significant effect on profitability. The growth rate has a positive and significant effect on profitability. And finally, efficiency has a positive and significant effect on profitability.
\end{abstract}

Keywords : profitability, capital structure, liquidity, growth rate, and efficiency.

Abstrak: Penelitian ini bertujuan untuk menguji pengaruh struktur modal, likuiditas, tingkat pertumbuhan, dan efisiensi terhadap profitabilitas. Penelitian ini memakai desain penelitian kuantitatif non-eksperimental dan metode perbandingan kausal (Ex-post Facto) dengan data sekunder (data diambil dari laporan keuangan perusahaan) dari 41 perusahaan Industri Properti, Real Estate, dan Building Construction di BEI periode 2014-2017. Sampel ditentukan dengan teknik judgemental sampling. Pengujian hipotesis melalui uji regresi linier ganda. Hasil penelitian menemukan bahwa secara empiris struktur modal memiliki pengaruh positif dan signifikan terhadap profitabilitas. Likuiditas memiliki pengaruh negatif dan tidak signifikan terhadap profitabilitas. Tingkat pertumbuhan memiliki pengaruh positif dan signifikan terhadap profitabilitas. Dan terakhir, efisiensi memiliki pengaruh positif dan signifikan terhadap profitabilitas.

Kata kunci : profitabilitas, struktur modal, likuititas, tingkat pertumbuhan, efisiensi

\section{Latar Belakang}

Menurut Marzuki (2002, pp: 64-67) industri properti dan perbankan diciptakan dengan dasar yang lemah dan model yang berantakan sejak tahun 1980-an. Pada masa tersebut pembisnis swasta menggunakan pinjaman kredit luar negeri yang bunganya lebih rendah dari pinjaman kredit di Indonesia tanpa upaya hedging, sehingga saat nilai rupiah jatuh hutang luar negeri mereka menjadi sangat berat. Selain itu banyak perusahaan yang menggunakan pendanaan jangka pendek untuk membiayai proyek jangka panjang.Pada tahun 2017-2018 industri properti mulai membaik dikarenakan pelonggaran kredit rumah dan loan to value, pengurangan PPh 22 dan PPnBM, serta dorongan dari sektor infrastruktur.

Keberhasilan perusahaan dapat dinilai dari tingkat profitabilitas yang dimiliki oleh perusahaan tersebut. Profitabilitas sebuah perusahaan dapat dipengaruhi oleh faktor-faktor internal maupun eksternal. Struktur modal, likuiditas, tingkat pertumbuhan, dan efisiensi memiliki peran penting di profitabilitas perusahaan. 
Pengambilan keputusan pendanaan mengacu pada Trade-off theory, yang merupakan sebuah ide bahwa perusahaan menentukan seberapa banyak pembiayaan dari hutang dan dari modal sendiri berdasarkan pertimbangan dari keuntungan dan biaya dari masing-masing alternatif yang tersedia. Dengan demikian berdasarkanTrade-off theory struktur modal memiliki pengaruh positif dan signifikan terhadap profitabilitas.Gillet al. (2011, pp: 3) menyatakan bahwa ada hubungan positif antara struktur modal (baik hutang jangka panjang maupun jangka pendek) dengan profitabilitas, sedangkan Omoregieet al. (2019, pp: 105) yang menemukan bahwa struktur modal memiliki dampak negatif terhadap profitabilitas. Selanjutnya keputusan tingkat likuiditas dapat mengacu pada teori pecking order yang menyatakan bahwa perusahaan pada awalnya mengandalkan dana internal (mis., Laba ditahan) di mana tidak ada keberadaan asimetri informasi. Jaworski dan Czerwonka (2018, pp: 326) meneliti hubungan likuiditas dan profitabilitas pada perusahaan yang terdaftar di Warsaw Stock Exchange menemukan bahwa ada hubungan signifikan antara likuiditas dan profitabilitas. İslatince (2015, pp: 175) menemukan bahwa likuiditas memiliki dampak negatif terhadap profitabilitas.

Kemudian peningkatan penjualan akan meningkatkan kapital margin yang diperoleh perusahaan sedangkan efisiensi perusahaan akan meminimalisasi biaya beban yang ditanggung perusahaan.Teori Resource-based view menjelaskan perusahaan yang dapat mempertahan sumber daya yang berharga, unik, sulit ditiru akan lebih mudah memperoleh keunggulan kompetitif. Sehingga dapat disimpulkan bahwa berdasarkan teori Resource-based view tingkat pertumbuhan memiliki pengaruh positif dan signifikan terhadap profitabilitas, selain itu efisiensi memiliki pengaruh positif dan signifikan terhadap profitabilitas.

Sivathaasanet al. (2013, pp: 99) menemukan bahwa tingkat pertumbuhan tidak memilki hubungan signifikan terhadap profitabilitas. Groweet al. (2014, pp: 231) menemukan bahwa tingkat pertumbuhan berdampak positif terhadap profitabilitas.Alarussi dan Alhaderi (2018, pp: 442) menemukan bahwa efisiensi perusahaan memiliki hubungan positif terhadap profitabilitas, sedangkanSantosuosso (2014, pp: 111) meneliti pengaruh efisiensi pada profitabilitas perusahaan menemukan bahwa ada hubungan positif antara efisiensi dengan profitabilitas.

Penelitian terdahulu mengenai hubungan antara struktur modal dan profitabilitas, likuiditas dan profitabilitas, tingkat pertumbuhan dan profitabilitas, serta efisiensi dan profitabilitas memiliki hasil yang berbeda satu sama lainnya. Sehingga penelitian ini bertujuan untuk menguji pengaruh struktur modal, likuiditas, tingkat pertumbuhan, dan efisiensi terhadap profitabilitas.

\section{KAJIAN TEORI}

Trade-off Theory. Menurut Sivalingam dan Kengatharan (2018, pp: 588) trade-off theory merupakan sebuah ide bahwa perusahaan menentukan seberapa banyak pembiayaan dari hutang dan dari modal sendiri berdasarkan pertimbangan dari keuntungan dan biaya dari masing-masing alternatif yang tersedia. Keseimbangan antara dead-weight costs of bankruptcy dan pengurangan pajak akan menguntungkan pembiayaan melalui hutang. Ebaid (2009, pp: 477) menemukan bahwa struktur modal memiliki dampak lemah-tidak ada pada performance. Gillet al. (2011, pp: 3) bahwa ada hubungan positif antara struktur modal dengan profitabilitas. Sivathaasanet al. (2013, pp: 99) menemukan bahwa struktur modal memiliki hubungan positif dan signifikan terhadap profitabilitas. Oleh karena itu penelitian ini mengambil asumsi bahwa struktur modal memiliki hubungan yang signifikan dan positif terhadap profitabilitas perusahaan. 
Pecking Order Theory. Myers dan Majluf (1984) dalam penelitian Gillet al. (2011, pp: 5) mengembangkan konsep struktur modal optimal berdasarkan gagasan informasi asimetris. Adanya asimetri informasi antara perusahaan dan penyedia dana menyebabkan biaya modal relatif bervariasi antara berbagai sumber keuangan. Sehingga Myers dan Majluf berpendapat bahwa perusahaan lebih suka menggunakan pendanaan internal daripada eksternal. Pendanaan eksternal hanya akan mengarah pada asimetri informasi yang akan meningkatkan biaya modal dan pada akhirnya mengurangi profit dan nilai perusahaan.Alarussi dan Alhaderi (2018, pp: 442) menemukan likuiditas tidak memiliki hubungan signifikan dengan profitabilitas. Qureshi dan Yousaf (2014, pp: 25) menemukan bahwa ukuran perusahaan, likuiditas, market share, dan umur perusahaan memiliki dampak positif terhadap profitabilitas, sedangkan intensitas modal dan tingkat pertumbuhan tidak memiliki dampak signifikan terhadap profitabilitas. Penelitian ini mengambil asumsi bahwa penggunaan likuiditas memiliki hubungan yang positif dan signifikan terhadap profitabilitas perusahaan.

Resource-Based View. Menurut Barney dalam penelitian Sheehan \& Foss (2007, pp: 451) Resource-Based View (RBV) menjelaskan mengapa perusahaan dengan sumber daya yang berharga, langka, tak dapat ditiru, dan terorganisasi dengan baik dapat menikmati kinerja yang unggul. Barney menyatakan bahwa fokus dari teori ini berada pada kepemilikan sumber daya yang dapat mempertahankan keunggulan kompetitif. Analisis RBV digambarkan dalam istilah yang sangat umum dan pada prinsipnya berlaku untuk sumber daya apa pun yang dimiliki perusahaan. Menurut Conner dan Prahalad dalam penelitian Yazdanfar dan Öhman (2015, pp: 533) perusahaan dapat menciptakan pertumbuhan penjualan, turnover, aset, dan tenaga kerja dengan memanfaatkan sumber dayanya secara efisien. Sivathaasan, Tharanika, Sinthuja, dan Hanitha (2013, pp: 99) menemukan bahwa tingkat pertumbuhan tidak memilki hubungan signifikan terhadap profitabilitas. Qureshi dan Yousaf (2014, pp: 25) menemukan bahwa tingkat pertumbuhan tidak memiliki dampak signifikan terhadap profitabilitas. Growe, DeBruine, Lee, dan Maldonado (2014, pp: 231) menemukan bahwa tingkat pertumbuhan berdampak positif terhadap profitabilitas.

Alarussi dan Alhaderi (2018, pp: 442) menemukan efisiensi perusahaan memiliki hubungan positif terhadap profitabilitas. Santosuosso (2014, pp: 111) meneliti pengaruh efisiensi pada profitabilitas perusahaan menemukan bahwa ada hubungan positif antara efisiensi dengan profitabilitas. Penelitian ini mengambil asumsi bahwa tingkat pertumbuhan memiliki pengaruh positif dan signifikan terhadap profitabilitas, selain itu efisiensi memiliki pengaruh positif dan signifikan terhadap profitabilitas.

\section{METODOLOGI}

Subyek penelitian adalah perusahaan yang bergerak di industri properti, real estate, dan building construction Indonesia serta terdaftar dalam Bursa Efek Indonesia periode 20142017, populasi sebanyak 81 perusahaan dan sampel sebesar 41 perusahaan.Teknik pemilihan sampel adalah non-probability samplingdengan metodejudgemental sampling. Obyek penelitian mencakup variabel dependen (profitabilitas) dan variabel independen (struktur modal, likuiditas, tingkat pertumbuhan, dan efisiensi). Penelitian dilakukan untuk memeriksa secara empiris apakah variabel independen memiliki pengaruh terhadap variabel dependen. Tabel 1 memperlihatkan operasionalisasi variabel dalam penelitian ini. 
Tabel 1. Operasionalisasi Variabel

\begin{tabular}{|c|c|c|c|}
\hline Variabel & Rumus & Skala & Acuan \\
\hline Profitabilitas & Return on equity $(\mathrm{ROE})=\frac{\text { net income }}{\text { total equity }}$ & Rasio & $\begin{array}{c}\text { Khan dan Ali (2017, pp: } \\
\text { 161) }\end{array}$ \\
\hline $\begin{array}{l}\text { Struktur } \\
\text { modal }\end{array}$ & Struktur modal $=\frac{\text { debt }}{\text { equity }}$ & Rasio & $\begin{array}{c}\text { Khan dan Ali (2017, pp: } \\
\text { 163) }\end{array}$ \\
\hline Likuiditas & Current ratio $=\frac{\text { currentassets }}{\text { current liabilities }}$ & Rasio & $\begin{array}{l}\text { Qureshi dan Yousaf (2014, } \\
\text { pp: 30) }\end{array}$ \\
\hline $\begin{array}{c}\text { Tingkat } \\
\text { Pertumbuhan }\end{array}$ & $\begin{array}{c}\text { Tingkat Pertumbuhan }= \\
\frac{\text { (Current year's sales }- \text { Last year's sal }}{\text { Last year' sales }}\end{array}$ & s) & $\begin{array}{c}\text { Sivathaasan, Tharanika, } \\
\text { Sinthuja, dan Hanitha (2013, } \\
\text { pp: 103) }\end{array}$ \\
\hline Efisiensi & $\begin{array}{c}\text { Accounts receivable turnover }= \\
\frac{\text { sales }}{\text { average account receivable ratic }} \\
\text { average account receivable ratio }= \\
\frac{\text { beginning accounts receivable +ending account }}{2}\end{array}$ & $\begin{array}{c}\text { Rasio } \\
\text { receivable }\end{array}$ & Santosuosso (2014, pp: 112) \\
\hline
\end{tabular}

Adapun uji statistik yang akan digunakan dalam penelitian ini adalah statistika dekriptif, uji hausman, uji regresi linier ganda, pengujian hipotesis, dan uji asumsi analisis data multikolinieritas. Pengolahan data panel melalui program EVIEW 9.0.

\section{HASIL UJI STATISTIK}

\section{Uji Asumsi Analisis Data Multikolinieritas}

Analisis korelasi digunakan untuk memeriksa peluang adanya hubungan dekat antara variabel independen (struktur modal, likuiditas, tingkat pertumbuhan, dan efisiensi). Tabel 2 memperlihatkan tingkat korelasi yang relative rendah sehingga variabel independen lulus uji multikolinieritas $(<0,80)$.Hubungan struktur modal dan likuiditas memiliki korelasi negatif, berarti semakin tinggi likuiditas yang dimiliki perusahaan maka semakin rendah pendanaan melalui hutang di struktur modal perusahaan demikian juga sebaliknya. Tingkat pertumbuhan memiliki korelasi negatif terhadap struktur modal berarti kenaikkan tingkat pertumbuhan penjualan akan membuat manajer menghindari pendanaan melalui hutang. Sebaliknya penurunan tingkat pertumbuhan penjualan akan membuat manajer melakukan pendanaan hutang di struktur modal lebih tinggi. 
Tingkat pertumbuhan juga memiliki korelasi negatif dengan likuiditas, berarti semakin tinggi pertumbuhan penjualan perusahaan maka semakin rendah likuiditas perusahaan dan sebaliknya. Struktur modal memiliki korelasi negatif terhadap efisiensi artinya bila terjadi kenaikkan efisiensi dimana perputaran piutang terjadi lebih cepat maka perusahaan biasanya menghindari pendanaan melalui hutang. Serta apabila terjadi kenaikkan pendanaan melalui hutang di struktur modal maka akan terjadi penurunan efisiensi. Efisiensi memiliki korelasi negatif dengan likuiditas berarti semakin cepat perputaran piutang maka semakin rendah likuiditas perusahaan demikian juga sebaliknya. Tingkat pertumbuhan juga memiliki korelasi negatif dengan efisiensi berarti peningkatan tingkat pertumbuhan penjualan akan menurunkan kecepatan perputaran piutang dan sebaliknya.

Tabel 2. Korelasi Antara Variabel Independen

\begin{tabular}{crrrr} 
& DER & \multicolumn{1}{c}{ CR } & GROW & \multicolumn{1}{c}{ EFI } \\
\hline \hline DER & 1.000000 & -0.368063 & -0.008950 & -0.153170 \\
CR & -0.368063 & 1.000000 & -0.039490 & -0.097430 \\
GROW & -0.008950 & -0.039490 & 1.000000 & -0.009785 \\
EFI & -0.153170 & -0.097430 & -0.009785 & 1.000000
\end{tabular}

\section{Statistika Deskriptif}

Berdasarkan hasil pengolahan data panel melalui program EVIEW 9.0 pada tabel 3 maka dapat diketahui bagaimana statistika deskriptif pada variabel profitabilitas, struktur modal, likuiditas, tingkat pertumbuhan, dan efisiensi.

Tabel 3. Descriptive statistics

\begin{tabular}{lrcccc}
\hline \hline & ROE & DER & CR & GROW & EFI \\
\hline \hline Mean & 0.090909 & 1.013938 & 2.331377 & 0.156491 & 11.44144 \\
Median & 0.090933 & 0.825280 & 1.626048 & 0.049199 & 7.056843 \\
Maximum & 0.322855 & 5.113060 & 10.06451 & 8.432627 & 56.71106 \\
Minimum & -0.509875 & 0.034693 & 0.207727 & -0.655436 & 0.983690 \\
Std. Dev. & 0.099517 & 0.884418 & 1.813323 & 0.764394 & 10.11232 \\
Skewness & -1.094323 & 1.938675 & 1.869811 & 8.172640 & 1.613623 \\
Kurtosis & 10.24946 & 7.891636 & 6.412896 & 86.29310 & 5.805757 \\
& & & & & \\
Jarque-Bera & 391.8569 & 266.2400 & 175.1563 & 49233.55 & 124.9638 \\
Probability & 0.000000 & 0.000000 & 0.000000 & 0.000000 & 0.000000 \\
& & & & & \\
Sum & 14.90911 & 166.2859 & 382.3458 & 25.66456 & 1876.396 \\
Sum Sq. Dev. & 1.614297 & 127.4979 & 535.9671 & 95.24066 & 16668.21 \\
Observations & 164 & 164 & 164 & 164 & 164
\end{tabular}

Setelah mengumpulkan data laporan keuangan tahun 2014-2017 dari 41 perusahaan yang terpilih dengan 164 observasi maka diketahui bahwa rata-rata profitabilitas sebesar 0.909 dengan nilai terendah -0.510 dan tertinggi 0.323 . Nilai standar deviasi sebesar 0.099 . Berikutnya struktur modal memiliki nilai rata-rata sebesar 1.014 dengan nilai terendah 0.035 
dan tertinggi 5.113. Nilai standar deviasi 0.884 hal ini menunjukkan variasi dalam penggunaan struktur modal cukup rendah. Likuiditas menunjukkan nilai rata-rata relative tinggi sebesar 2.331 dengan nilai minimal 0.208 dan tertinggi sebesar 10.064. nilai standar deviasi 1.813. Tingkat pertumbuhan memiliki rata-rata 0.156 dengan nilai minimum -0.655 dan nilai maximum 8.433. Nilai standar deviasi 0.764 . Terakhir efisiensi memiliki nilai ratarata relative tinggi sebesar 11.441 dengan nilai minimum 0.984 dan nilai maximum 56.711. Nilai standar deviasi relative tinggi sebesar 10.112 sehingga dapat disimpulkan adanya variasi tinggi dalam mengelola perputaran piutang perusahaan.

\section{Uji Hausman}

Hausman-test dilakukan untuk menentukan metode estimasi BLUE (Best Linier Unbiased Estimator) melalui perbandingan hasil metode random effect dan fixed effect. Hasil Probability value chi square bernilai lebih dari 5\%, maka persamaan regresi yang sebaiknya digunakan adalah random effects testing yang menunjukkan bahwa tidak terdapat kemiripan pada keterkaitan antar variabel pada tiap-tiap perusahaan yang menjadi sampel.

Tabel 4. Hasil Uji Hausman

\begin{tabular}{lrrr}
\hline \hline Test Summary & $\begin{array}{r}\text { Chi-Sq. } \\
\text { Statistic }\end{array}$ & Chi-Sq. d.f. & Prob. \\
\hline \hline Cross-section random & 5.047760 & 4 & 0.2824 \\
\hline \hline
\end{tabular}

\section{Uji Regresi Linier Ganda dan Hipotesis}

Variabel independen akan dinilai signifikan terhadap variabel dependen apabila nilai probabilitasnya kurang dari 5\%. Berdasarkan hal tersebut maka dari tabel 5 dapat disimpulkan secara empiris bahwa struktur modal, tingkat pertumbuhan, dan efisiensi memiliki pengaruh positif dan signifikan terhadap profitabilitas. Sedangkan likuiditas memiliki pengaruh negatif dan tidak signifikan terhadap profitabilitas.

\section{Koefisien Determinasi}

Koefisien ini memperlihatkan proposi dari variabel dependen yang sanggup dijelaskan oleh proposi variabel independen. Sehingga berdasarkan tabel 5 variabel profitabilitas dapat dijelaskan sebesar $8.91 \%$ oleh proporsi variabel struktur modal, likuiditas, tingkat pertumbuhan, dan efisiensi sedangkan sisanya dijelaskan oleh variabel lain.

Tabel 5. Hasil Analisis Regresi Linier Ganda

\begin{tabular}{crrrr}
\hline \hline Variable & Coefficient & Std. Error & t-Statistic & Prob. \\
\hline \hline C & 0.055853 & 0.024710 & 2.260345 & 0.0252 \\
DER & 0.024965 & 0.010717 & 2.329343 & 0.0211 \\
CR & -0.006597 & 0.004873 & -1.353804 & 0.1777 \\
GROW & 0.015978 & 0.007600 & 2.102548 & 0.0371 \\
EFI & 0.001977 & 0.000831 & 2.378530 & 0.0186 \\
\hline \hline & Effects Specification & & \\
\hline \hline
\end{tabular}




\begin{tabular}{lll} 
Cross-section random & 0.067899 & 0.5016 \\
Idiosyncratic random & 0.067676 & 0.4984 \\
\hline
\end{tabular}

\begin{tabular}{|c|c|c|c|}
\hline \multicolumn{4}{|c|}{ Weighted Statistics } \\
\hline R-squared & 0.111461 & Mean dependent var & 0.040549 \\
\hline Adjusted R-squared & 0.089108 & S.D. dependent var & 0.071142 \\
\hline S.E. of regression & 0.067898 & Sum squared resid & 0.733022 \\
\hline F-statistic & 4.986354 & Durbin-Watson stat & 2.038910 \\
\hline Prob(F-statistic) & 0.000820 & & \\
\hline \multicolumn{4}{|c|}{ Unweighted Statistics } \\
\hline R-squared & 0.084301 & Mean dependent var & 0.090909 \\
\hline Sum squared resid & 1.478211 & Durbin-Watson stat & 1.011064 \\
\hline
\end{tabular}

\section{DISKUSI}

Berbasis pada data yang telah dikumpulkan dan diolah melalui uji statistik deskriptifnya berikut adalah kecenderungan dari masing-masing variabel yang diuji:

\section{Determinasi Struktur Modal terhadap Profitabilitas}

Berdasarkan hasil pengujian ditemukan bahwa struktur modal memiliki pengaruh positif dan signifikan terhadap profitabilitas, hal ini dapat dilihat dari nilai signifikasi struktur modal (DER) sebesar $0.0211,0.0211<0.05$ sehingga struktur modal berpengaruh signifikan terhadap profitabilitas. Koefisien struktur modal terhadap profitabilitas positif berarti semakin tinggi pendanaan melalui hutang yang dilakukan perusahaan maka semakin tinggi tingkat profitabilitas yang akan dihasilkan perusahaan.

Hal ini dikarenakan perusahaan memanfaat penghematan pajak dari potongan bunya hutang. Selain itu dengan melakukan pendanaan melalui hutang maka perusahaan menjaga nilai ekuitasnya tetap ketika melakukan ekspansi dan sebagainya. Dengan demikian hipotesis 1 yang menyatakan bahwa struktur modal memiliki pengaruh terhadap profitabilitas secara positif diterima. Hasil penelitian sejalan dengan Trade-off theory yang merupakan sebuah ide bahwa perusahaan menentukan seberapa banyak pembiayaan dari hutang dan dari modal sendiri berdasarkan pertimbangan dari keuntungan dan biaya dari masing-masing alternatif yang tersedia.

Hasil penelitian ini sejalan dengan hasil penelitian Gillet al. (2011, pp: 3) bahwa ada hubungan positif antara struktur modal (baik hutang jangka panjang maupun jangka pendek) dengan profitabilitas perusahaan layanan dan manufaktur Amerika. Sivathaasan et al.(2013, pp: 99) menemukan bahwa struktur modal memiliki hubungan positif dan signifikan terhadap profitabilitas. Namun hasil penelitian berbeda dengan penelitian Omoregieet al. (2019, pp: 105) yang menemukan bahwa struktur modal memiliki dampak negatif terhadap profitabilitas. Perbedaan hasil penelitian ini kemungkinan dikarenakan perbedaan sampel dan demografi subyek penelitian.

\section{Determinasi Likuiditas terhadap Profitabilitas}

Berdasarkan hasil pengujian ditemukan bahwa likuiditas memiliki pengaruh negatif dan tidak signifikan terhadap profitabilitas, hal ini dapat dilihat dari nilai signifikasi likuiditas (CR) sebesar $0.1777,0.1777>0.05$ sehingga likuiditas berpengaruh tidak signifikan terhadap profitabilitas. Koefisien likuiditas terhadap profitabilitas negatif berarti semakin tinggi tingkat 
likuiditas yang dimiliki perusahaan maka semakin rendah tingkat profitabilitas yang akan dihasilkan perusahaan. Hal ini dikarenakan perusahaan yang memiliki tingkat likuiditas tinggi memiliki banyak aset lancar, sehingga biaya bebannya tinggi dan mengurangi profitabilitas.

Dengan demikian hipotesis 2 yang menyatakan bahwa likuiditas memiliki pengaruh terhadap profitabilitas secara positif ditolak. Hasil penelitian tidak sejalan dengan teori Pecking order theory yang berbasis pada adanya ketidaksetaraan informasi antara manajer perusahaan dan investor. Akibatnya, sering ada perbedaan pandangan tentang kebijakan yang diambil oleh manajer perusahaan. Sehingga Myers dan Majluf berpendapat bahwa perusahaan lebih suka menggunakan pendanaan internal daripada eksternal. Pendanaan eksternal hanya akan mengarah pada asimetri informasi yang akan meningkatkan biaya modal dan pada akhirnya mengurangi profit dan nilai perusahaan.

Hasil penelitian ini sesuai dengan penelitian Zainudinet al. (2018, pp: 533) bahwa likuiditas memiliki hubungan tidak signifikan dengan profitabilitas. Alarussi dan Alhaderi (2018, pp: 442) menemukan bahwa likuiditas tidak memiliki hubungan signifikan dengan profitabilitas. Selain itu İslatince (2015, pp: 175) menemukan bahwa likuiditas memiliki dampak negatif terhadap profitabilitas. Namun penelitian ini tidak sejalan dengan penelitian Qureshi dan Yousaf (2014) yang menemukan bahwa likuiditas memiliki hubungan positif dan signifikan dengan profitabilitas.

\section{Determinasi Tingkat Pertumbuhan terhadap Profitabilitas}

Berdasarkan hasil pengujian ditemukan bahwa tingkat pertumbuhan memiliki pengaruh positif dan signifikan terhadap profitabilitas, hal ini dapat dilihat dari nilai signifikasi tingkat pertumbuhan (GROW) sebesar 0.0371, $0.0371<0.05$ sehingga tingkat pertumbuhan berpengaruh signifikan terhadap profitabilitas. Koefisien tingkat pertumbuhan terhadap profitabilitas positif berarti semakin tinggi tingkat pertumbuhan penjualan yang dihasilkan perusahaan maka semakin tinggi profitabilitas yang akan diperoleh perusahaan. Hasil penelitian sesuai dengan teori Resource-Based View (RBV) yang menjelaskan bahwa perusahaan dengan sumber daya yang berharga, langka, tak dapat ditiru, dan terorganisasi dengan baik dapat menikmati kinerja yang unggul.Hasil penelitian sejalan dengan penelitian Yazdanfar (2013, pp: 150) menemukan tingkat pertumbuhan berpengaruh positif terhadap profitabilitas. Namun hasil penelitian ini bertentangan dengan penelitian Qureshi dan Yousaf (2014, pp: 25) tingkat pertumbuhan memiliki hubungan negatif dan tidak signifikan terhadap profitabilitas.

\section{Determinasi Efisiensi terhadap Profitabilitas}

Berdasarkan hasil pengujian ditemukan bahwa efisiensi memiliki pengaruh positif dan signifikan terhadap profitabilitas, hal ini dapat dilihat dari nilai signifikasi efisiensi (EFI) sebesar $0.0186,0.0186<0.05$ sehingga efisiensi berpengaruh signifikan terhadap profitabilitas. Koefisien efisiensi terhadap profitabilitas positif berarti semakin tinggi efisiensi yang dimiliki perusahaan maka semakin tinggi tingkat profitabilitas yang akan diperoleh perusahaan. Hasil peneltian sesuai dengan teori Resource-Based View (RBV) yang menjelaskan bahwa perusahaan dengan sumber daya yang berharga, langka, tak dapat ditiru, dan terorganisasi dengan baik dapat menikmati kinerja yang unggul. Hasil penelitian sejalan dengan Santosuosso (2014, pp: 111) meneliti pengaruh efisiensi pada profitabilitas perusahaan menemukan bahwa ada hubungan positif antara efisiensi dengan profitabilitas. Penelitian ini juga sejalan dengan hasil penelitian Alarussi dan Alhaderi (2018, pp: 442) meneliti faktor-faktor yang mempengaruhi profitabilitas di perusahaan go public Malaysia bahwa efisiensi perusahaan memiliki hubungan positif terhadap profitabilitas. 


\section{KESIMPULAN}

Keterbatasan penelitian ini seperti database terbatas pada 41 perusahaan Industri Properti, Real Estate, dan Building Construction dan mencangkup periode 2014-2017. Hasil penelitian dapat diggunakan untuk membantu manajer menentukan kebijakkan struktur modal dan likuiditas secara optimal demi kepentingan perusahaan serta membantu menentukan tingkat pertumbuhan dan efisiensi perusahaan yang sebaiknya dicapai. Penelitian ini juga membantu manajer membuat kebijakannya sesuai dengan keinginan pemilik saham dan struktur organisasinya.

\section{DAFTAR PUSTAKA}

Alarussi, A.S., Alhaderi, S.M. (2018). Factors affecting profitability in Malaysia. Journal of Economic Studies, 45(3), 442-458.

Chandra, T., Junaedi, A. T., Wijaya, E., Suharti, S., Mimelientesa, I., and Ng, M. (2019). The eff ect of capital structure on profitability and stock returns. Journal of Chinese Economic and Foreign Trade Studies, 12(2), 74-89.

Ebaid, I.E. (2009). The Impact of Capital-Structure Choice on Firm Performance: Empirical Evidence from Egypt. The Journal of Risk Finance, 10(5), 477-487.

Gill, A., Biger, N., \& Mathur, N. (2011). The Effect of Capital Structure on Profitability: Evidence from the United States. International Journal of Management, 28(1), 3-15.

Growe, G., DeBruine, M., Lee, J.Y., and Maldonado, J.F.T. (2014). The Profitability and Performance Measurement of U.S. Regional Banks Using the Predictive Focus of The "Fundamental Analysis Research". Advances in Management Accounting, 24, 189237.

İslatince, N. (2015). Analysis of the Factors that Determine the Profitability of the Deposit Banks in Turkey. Journal of Applied Finance \& Banking, 5(3), 175-186.

Jaworski, J., \& Czerwonka, L. (2018). Relationship between Profitability and Liquidity of Enterprises Listed on Warsaw Stock Exchange. 35th International Scientific Conference on Economic and Social Development, 326-334.

Khan, H, A., \& Ali, Q. (2017). Impact of Dividend Policy and Capital Structure on Profitability of Firms: A Comparative study between Food and Cement Sector of Pakistan Stock Exchange. University of Haripur Journal of Management(UOHJM), 2(1), 159-174.

Marzuki, M. (2002). Restrukturisasi Kredit Sektor Porperti dan Real Estate. Jurnal Hukum, 9(19), $64-80$.

Omoregie, O.K., Olofin, S.A., \& Ikpesu, F. (2019). Capital Structure and the ProfitabilityLiquidity Trade-off. International Journal of Economics and Financial Issues, 9(3), 105-115.

Qureshi, M.A., \& Yousaf, M. (2014). Determinants of profit heterogeneity at firm level: evidence from Pakistan. International Journal of Commerce and Management, 24(1), 25-39.

Santosuosso, P. (2014). Do Efficiency Ratios Help Investors to Explore Firm Performances? Evidence from Italian Listed Firms. International Business Research, 7(12), 111-119.

Sheehan, N.T., \& Foss, N.J. (2007). Enhancing the prescriptiveness of the resource-based view through Porterian activity analysis. Management Decision, 45(3), 450-461. 
Sivalingam, L. \& Kengatharan, L. (2018). Capital Structure and Financial Performance: A Study on Commercial Banks in Sri Lanka. Asian Economic and Financial Review, 8(5), 586-598.

Sivathaasan, N., Tharanika, R., Sinthuja, M., Hanitha, V. (2013). Factors determining Profitability: A Study of Selected Manufacturing Companies listed on Colombo Stock Exchange in Sri Lanka. European Journal of Business and Management, 5(27), 99107.

Yazdanfar, D., and Öhman, P. (2015). The growth-profitability nexus among Swedish SMEs. International Journal of Managerial Finance, 11(4), 531-547.

Yazdanfar, D. (2013). Profitability determinants among micro firms: evidence from Swedish data. International Journal of Managerial Finance, 9(2), 150-160.

Zainudin, R., Mahdzan, N.S.A., and Leong, E.S. (2018). Firm-specific internal determinants of profitability performance: an exploratory study of selected life insurance firms in Asia. Journal of Asia Business Studies, 12(4), 533-550.

https://www.idx.co.id/ 